\title{
Effectiveness of Biostimulants Amendment with Indigenous Microbes on Bioremediation of Crude Oil Contaminated Soil in Niger Delta Region of Nigeria
}

\author{
${ }^{1}$ Umeojiakor C.T, ${ }^{1}$ Ojiabo, K.T \\ ${ }^{1}$ Department of Chemical Engineering, \\ Federal Polytechnic Nekede, Owerri, \\ Imo State Nigeria \\ ${ }^{2}$ Umeojiakor A.O \\ ${ }^{2}$ Department of Forestry and Wildlife Technology, \\ Federal University of Technology Owerri, \\ Imo State Nigeria
}

\begin{abstract}
Crude oil polluted soils, pose a serious threat to environmental receptors and human health. The need to reduce its considerable impact on the environment required adequate knowledge of remediation technology. This study aimed at investigating the best plant supplement (sawdust, pumpkin leaves and wood ash) and indigenous microorganisms capable of degrading crude oil contaminated soils of Niger Delta region. Soil sample was collected from the top surface soil $(0-15 \mathrm{~cm})$ in Odii River bank, in Egi community, Omoku, River State. Soil sample was air dried and Sterilized by autoclaving at $1^{\circ} \mathrm{C}$ for an hour. Plant organic carbon source; saw dust, pumpkin leaves and wood ash were oven dried and grinded. The isolation and identification process was evaluated by staining method, microscopic examination and biochemical tests. $400 \mathrm{~g}$ of sterilized soil was mixed with $50 \mathrm{~g}$ of crude oil in each of the microcosm, labeled $B 1$ to $B 5$. The experimental set up was allowed to stand for 24hour, inoculated with $20 \mathrm{ml}$ of microbial broth containing Aspergillus niger and Pseudomonas aereginosa as agent(s) of degradation. Microcosm B1 to B3 was amended, each with wood ash, pumpkin leave and saw dust respectively, microcosm B4 was with microorganisms alone and $B 5$ served as control experiment. The effectiveness of bioremediation process was monitored using the total petroleum hydrocarbon removal (TPH) every 7 days for remediation period of 49days, at room temperature. The results obtained from microbial isolation showed that Aspergillius niger and Pseudomona aereginosa were the most populated in the soil and were selected. Microcosm B2 with pumpkin leave had the highest TPH removal rate $(91.08 \%)$, followed by $B 1$ with wood ash $(88.62 \%)$, B3 with sawdust $(62.61 \%)$, B4 without supplement $(69.49 \%)$ and $\mathrm{B} 5$ control experiment $(3.42 \%)$. From the study, it was ascertained that pumpkin leave and wood ash were effective in degrading crude oil contaminated soil but sawdust appeared to have inhibited the activities of the microbes as this gave a lower efficiency compared to B4 without supplement.
\end{abstract}

Keywords: Bioremediation; Crude oil; Microorganisms; Plant supplements; Microcosm.

\author{
${ }^{3}$ Anyikwa S.O \\ ${ }^{3}$ Department of Chemical Engineering, \\ Federal University of Technology Owerri, \\ Imo State Nigeria \\ ${ }^{4}$ Nwanwe C.C. \\ ${ }^{4}$ Department of Minerals and Petroleum Resources \\ Engineering Technology, \\ Federal Polytechnic Nekede Owerri, \\ Imo State Nigeria.
}

\section{INTRODUCTION}

Crude oil is a naturally occurring, unrefined petroleum product composed of large variety of hydrocarbons deposits and other organic compounds including organometallic constituents [1]. It is often referred to as "black gold." According to [2], Crude oil is considered as one of the most important source of energy for various industries and income that plays a key role in economic development of a country. Many activities such as industrial and municipal runoffs, effluent release, offshore and onshore petroleum industry activities as well as accidental spills cause petroleum hydrocarbon pollution. [3], noted that the extensive use of crude oil and other petroleum products, due to increase in industrial activities, has led to the intrusion of petroleum hydrocarbon compounds into soil environments by various routes, such as leakage from underground storage tanks (UST) and pipelines, accidental spills usually from the exploration, production, refining, transport, storage of petroleum and its products. The disaster arising from such incidence has shown to have harmful effects on the environment and human being, since crude oil contains a wide range of compounds that can pose a significant risk for the environment and human health. Various constituents of petroleum hydrocarbon compounds may enter the human system via inhalation, ingestion, or dermal contact and may pose hepatic, renal, neurological, and/or respiratory risks. [4], reported that these contaminants affects the chemical composition and physical matrix of soils calumniating to the loss of soil fertility, change in ecosystem and displacement of communities. The contamination of soil by crude oil has become a serious problem that represents a global concern due to the potential consequences on ecosystem and human health [5]. Also it has been reported by [6], that soil contaminated by spillage of crude oil during the processes of petroleum exploration, transportation, storage and refining is a worldwide environmental problem. Spilled petroleum enters surface 
water, ground water and soil, it attaches to plant roots and gets absorbed by the plants and through the food web ultimately reach humans, affecting human health. Reducing the petroleum hydrocarbon compounds in a polluted environment becomes a significant challenge for oil companies and this has led to the development of sophisticated remediation technologies for the clean-up of contaminated soils and sediments. Many physical and chemical methods have been developed to remediate petroleum contaminated soil such as soil removal, incineration, soil washing, burying, dispersion, UV oxidation and soil vapour extraction [7]. However, most of these methods are expensive and have high energy demands, causing secondary contamination. These methods can be very effective at reducing levels of a range of contaminants, but have several drawbacks, principally their technological complexity, the cost for small-scale application, and the lack of public acceptance, especially for incineration that may increase the exposure to contaminants for both the workers at the site and nearby residents [8]; [9]; [10]. For this reason an increasing attention has been directed toward the research of new strategies and environmental-friendly technologies for the remediation of soil contaminated by petroleum hydrocarbons.

Bioremediation has been regarded as a cost-effective method that can be easily implemented and is environmentally friendly although it is usually timeconsuming compared with other physical or chemical remediation methods which hinder its application [24]. Bioremediation refers to the metabolic ability of living organisms, primarily microorganisms (bacteria and fungi) to degrade (transform or convert) the environmental contaminants into less form of compounds (harmless end products). [11], opined that bioremediation provides the most cost-effective and eco-friendly measurements for the remediation petroleum contaminated soil and water to bring back its native environment. Conservation of soil texture and characteristics are among the advantages of bioremediation. Besides, physical and chemical properties of the soil such as aeration, $\mathrm{pH}$, water holding capacity and ion exchange capacity can be improved after bioremediation [12]. Bioaugmentation and biostimulation are the two main methods that can accelerate biodegradation. Bioaugmentation introduces active microorganisms into the contaminated sites while biostimulation is based on stimulation of the catabolic activity of indigenous microorganisms by the addition of nutrient-rich organic and inorganic materials, supplying oxygen, nitrogen, phosphorus or other electrons acceptors, and by maintaining suitable conditions of temperature, $\mathrm{pH}$ and moisture [13]; [14]; and [15]. Biostimulation has been proven to be a promising bioremediation technique for the treatment of polluted soil aerobically [16]; and [17]. The biostmulants thus provided, maintains the favourable condition for growth of the microorganisms. This singular act is only possible through biodegradation which are facilitated by indigenous soil microbes. In this research work, the rate of bioremediation was studied by use of various stimulants (organic carbon source of wood ash, pumpkin leaves and saw dust) capable of providing nutrients to enhance indigenous microbes (Aspergillius niger and Pseudomonas aereginosa) biodegradation of crude oil contaminated soil in the Niger Delta region of Nigeria.

\section{MATERIALS AND METHOD}

The study was carried out in Luco Scientific Laboratory, Benin. Crude oil used, was obtained from the Nigeria Petroleum Corporation, Warri, Delta State, Nigeria while soil sample was collected from the top surface soil $(0-$ $15 \mathrm{~cm}$ ) in Odii river bank, Egi community, Omoku, River State, Nigeria with the aid of stainless steel trowel and gloved hands and stored in a polyethylene bag. Soil sample was air dried in order to reduce the moisture content and was sieved using $2 \mathrm{~mm}$ mesh to ensure homogeneity. Sterilization of soil sample was done by autoclaving at $120^{\circ} \mathrm{C}$ for an hour in order to remove indigenous microorganisms in the soil. Plant organic carbon source of saw dust, pumpkin leaves and wood ash was obtained in Owerri City. These organic wastes were each oven dried to reduce moisture content and then ground for a better surface area. The isolation and identification analysis was evaluated by staining method in microbiology laboratory, University of Benin. 400g of sterilized soil was mixed with $50 \mathrm{~g}$ of crude oil in each of the microcosm, labeled B1 to B5 with vent holes at the lid of the microcosm and at the sides, plugged with sterile cotton wool to ensure maximum protection of cross contamination and at the same time enhance aerobic respiration. The mixture was stirred thoroughly and homogeneous contamination of soil with crude oil was achieved. The set up was allowed to stand for 24 hours for sequestration into the soil micro pores, after which, the content was inoculated with $20 \mathrm{ml}$ of microbial broth containing Aspergillus niger and Pseudomonas aereginosa as agent(s) of degradation. Microcosm B1 to B3 was amended, each with wood ash, pumpkin leave and saw dust respectively, while microcosm B4 was with microorganisms alone and B5 served as control experiment i.e. natural attenuation. That is to say that B5 was not amended. The organic carbon amended soil was agitated vigorously in mechanical shaker for uniformity. The water content of the soil in each of the bioreactor (microcosm) was maintained with sterile distilled water to its moisture holding capacity. Sampling for quantitative analysis was carried out every seven days, by solid-liquid extraction method to determine Total Petroleum Hydrocarbon content (TPH). Percentage degradation was determined with:

$$
D=\frac{\left[R H C_{i}-R H C_{r}\right]}{R H C_{i}} \times 100
$$

Where $\mathrm{RHC}_{\mathrm{i}}$ and $\mathrm{RHC}_{\mathrm{r}}$ depict the initial and residual TPH concentration obtained at the end of each week respectively, [18].

\section{RESULTS AND DISCUSSION}

The results of the Total Petroleum Hydrocarbon (TPH) removal from the soil at the end of every week were depicted in table 1 . The removal effect of TPH 
concentration in the crude oil contaminated soil was used as an indicator parameter for remediation from the first week to the end of the seventh week (49 days) and these were observed to reduce with time for various

Table 1: Total Petroleum Hydrocarbon (TPH) Removal at the end of every week.

\begin{tabular}{|c|c|c|c|c|c|}
\hline Week & $\begin{array}{l}\text { B1(wood ash) } \\
\text { TPH } \\
\mathrm{mg} / \mathrm{kg}\end{array}$ & $\begin{array}{l}\text { B2( pumpkin leave) } \\
\text { TPH } \\
\mathrm{mg} / \mathrm{kg}\end{array}$ & $\begin{array}{l}\text { B3(saw dust) } \\
\text { TPH } \\
\mathrm{mg} / \mathrm{kg}\end{array}$ & $\begin{array}{l}\text { B4(without } \\
\text { supplement) } \\
\text { TPH } \\
\mathrm{mg} / \mathrm{kg}\end{array}$ & $\begin{array}{l}\text { B5(control } \\
\text { experiment) } \\
\mathrm{TPH} \\
\mathrm{mg} / \mathrm{kg} \\
\end{array}$ \\
\hline 0 & 911.1 & 914.7 & 924.7 & 912.6 & 907.9 \\
\hline 1 & 549.5 & 497.9 & 912.6 & 820.0 & 907.4 \\
\hline 2 & 428.9 & 276.3 & 875.3 & 752.6 & 901.6 \\
\hline 3 & 276.8 & 151.6 & 873.7 & 571.1 & 887.9 \\
\hline 4 & 159.5 & 125.3 & 740.5 & 495.8 & 885.8 \\
\hline 5 & 131.6 & 99.5 & 454.7 & 308.9 & 644.2 \\
\hline 6 & 107.4 & 84.2 & 360.0 & 286.3 & 606.8 \\
\hline 7 & 103.7 & 81.6 & 345.8 & 278.4 & 876.8 \\
\hline
\end{tabular}

applied carbon organic source of wood ash, pumpkin leave and saw dust (Biostimulants). The decrease in concentration of Total Petroleum hydrocarbon in the crude oil contaminated soil can be attributed to the decomposition of the hydrocarbon by the microorganisms to harmless or less harmful substance. [19], suggested that the reduction in TPH values indicates reduction in the crude oil content of the contaminated soils degraded by the microorganisms to harmless products such as $\mathrm{CO}_{2}$ and $\mathrm{H}_{2} \mathrm{O}$.

The significant reduction in the content of TPH was observed in the microcosm B2 with pumpkin leave and microcosm B1 with wood ash amended soil samples compared to the saw dust amended soil sample within the first three weeks (21days) of the remediation period. This can be attributed to high nutrient content of pumpkin leave and wood ash. [20], reported that the additional nutrient nitrogen and phosphorus contained in the organic materials stimulate microbial growth and led to synthesized enzymes required to degrade petroleum hydrocarbon compounds. Similar observations have been reported that the nutrient availability stimulates the growth of microorganism and biodegradation of the polycyclic aromatic hydrocarbon (PAH) contaminated soils [21].

Table 2: Percent degradation of Crude oil at the end of seven weeks

\begin{tabular}{|c|l|l|l|l|l|}
\hline Week & $\begin{array}{l}\text { B1(wood ash) } \\
(\%)\end{array}$ & $\begin{array}{l}\text { B2( pumkin leave) } \\
(\%)\end{array}$ & $\begin{array}{l}\text { B3(saw dust) } \\
(\%)\end{array}$ & $\begin{array}{l}\text { B4(without } \\
\text { supplement) } \\
(\%)\end{array}$ \\
\hline 0 & 0 & 0 & 0 & 0 & $\begin{array}{l}\text { B5(control } \\
\text { experiment) } \\
(\%)\end{array}$ \\
\hline 1 & 39.69 & 45.57 & 1.31 & 10.15 & 0 \\
\hline 2 & 52.92 & 69.79 & 5.35 & 17.53 & 0.06 \\
\hline 3 & 69.61 & 83.43 & 5.52 & 37.43 & 0.69 \\
\hline 4 & 82.50 & 86.31 & 19.92 & 45.67 & 2.20 \\
\hline 5 & 85.56 & 90.13 & 50.82 & 66.15 & 2.43 \\
\hline 6 & 88.21 & 91.08 & 61.07 & 68.63 & 2.90 \\
\hline 7 & 88.62 & 62.61 & 69.49 & 3.32 \\
\hline
\end{tabular}

The Percentage degradation of crude oil at the end of seven weeks was shown in table 2. The results displayed, Convinced percentage degradation of crude oil was achieved at the end of remediation process in the decreasing order $\mathrm{B} 2>\mathrm{B} 1>\mathrm{B} 4>\mathrm{B} 3>\mathrm{B} 5$. Microcosm B2 amended with pumpkin leave had the highest percentage degradation of $91.08 \%$ followed by microcosm B1 with wood ash $88.62 \%$, Microcosm B4 without supplement had $69.49 \%$, Microcosm B3 added with saw dust (62.61\%) and Microcosm B5 (control experiment) had the least percentage degradation of $3.42 \%$ (fig 1). It was observed that the use of plant supplements as biostimulant yielded a good results in the microcosms. This is in agreement with the findings of [22] that crude oil polluted soil amended with organic matter may stimulate growth of the indigenous oil degrading microbiota in it. [23] noted that the addition of organic wastes amendment increases the solubility and availability of hydrocarbons to biodegrading bacteria and contributes to the biodegradation of petroleum hydrocarbons. [24], also reported similar findings with organic amendment. Sawdust appeared to be inhibited the activities of microbes as this gave a lower efficiency compared to reactor B4 which without supplement. Though there was a very little depletion in the concentration of control experiment due to volatilization or by natural attenuation caused by residual microbes which could result from contaminations from air and water.

It was observed from figure 2, that the degradation process was fast within the first three weeks. The curves got from the activities of microorganisms in the bioreactors with and without plant supplements is a clear indication of the efficiency of nutrients amendment in degradation of bioavailable hydrocarbon content. 


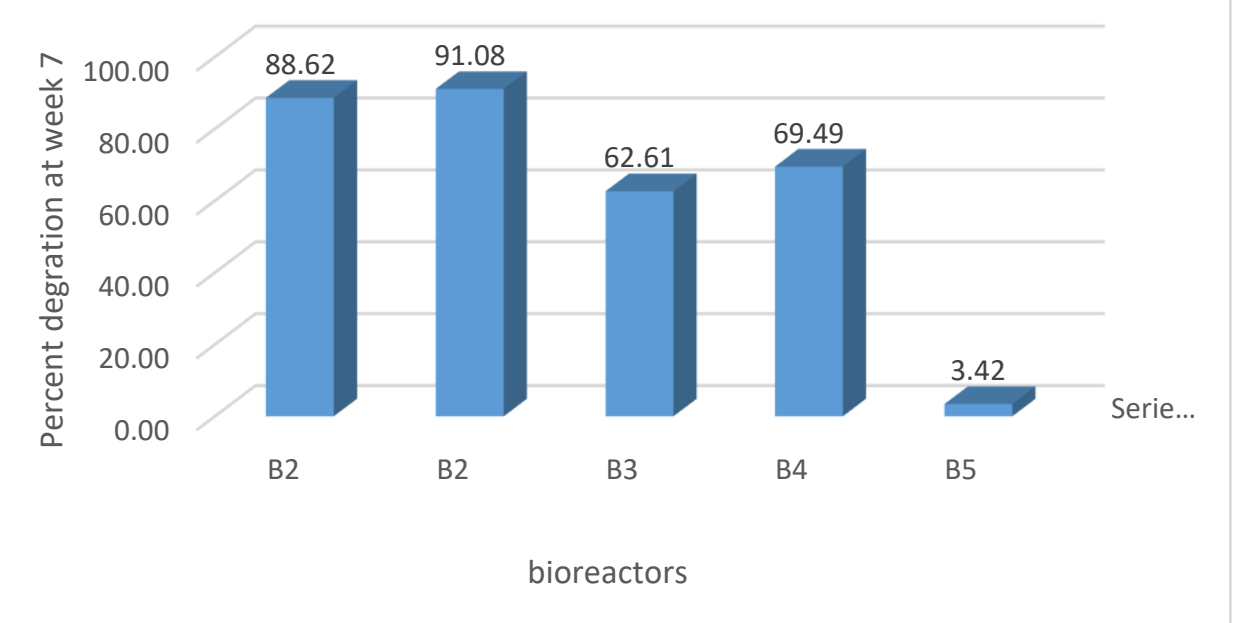

Figure 1: Percentage degradation of crude oil at the end of seven weeks

The curves were observed to be horizontal from week four, indicating that substrate (hydrocarbon) were no longer bioavailable after a continuous mineralization by microbes. Curve B4 were obtained from reactor without supplements, which revealed essential microbial degradation of crude oil in the soil. But the highest concentration depletion occurred in the microcosms containing pumpkin, $91.08 \%$, followed by wood ash, $88.62 \%$.

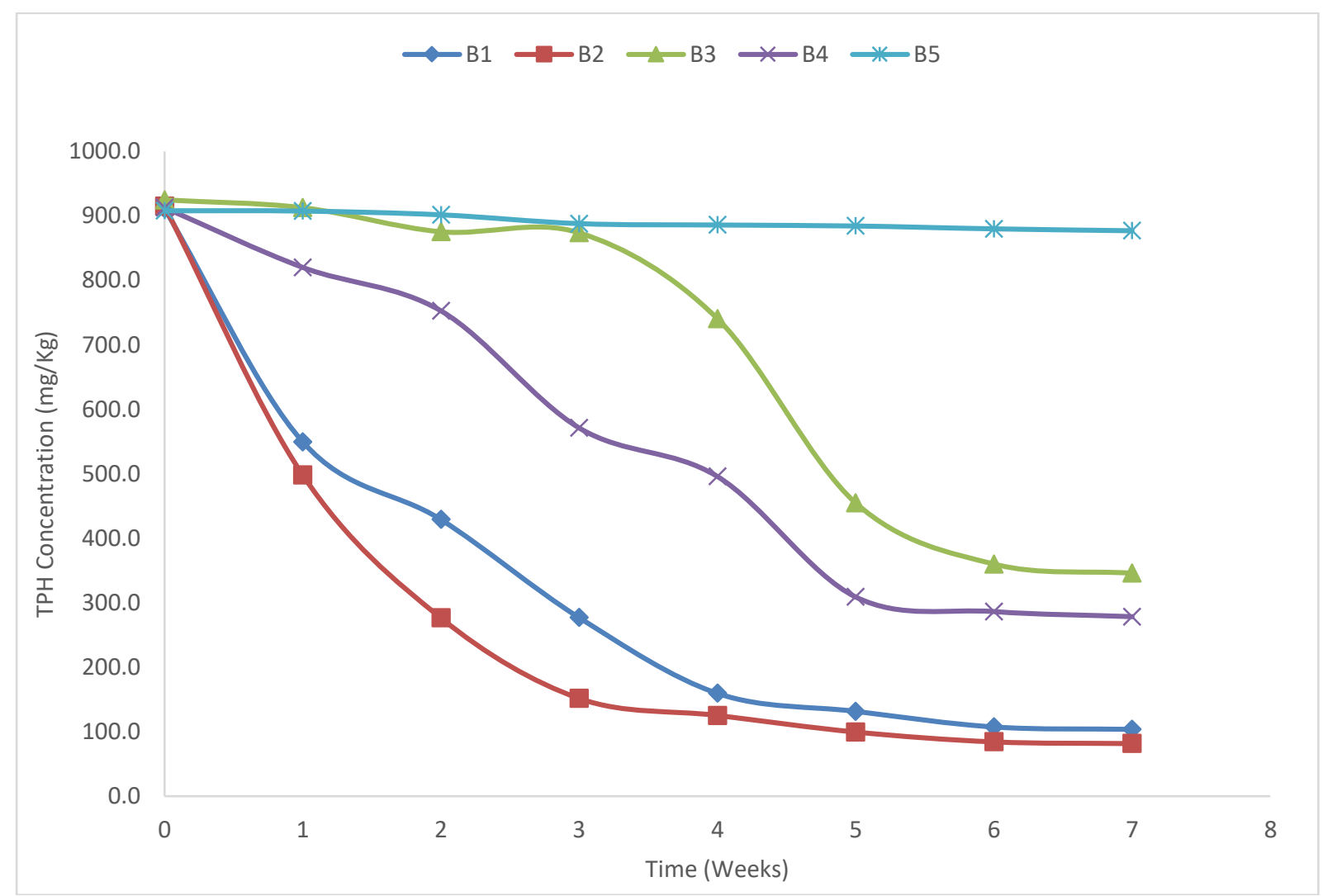

Fig2: Total petroleum hydrocarbon content during remediation period

CONCLUSION

The rate of bioremediation was studied by the use of various stimulants of organic carbon source (wood ash, pumpkin leave and saw dust) capable of providing nutrients to enhanced indigenous microbes (Aspergillius niger and Pseudomona aereginosa) in biodegradation of crude oil contaminated soil. From the study, it was ascertained that the percentage degradation of total hydrocarbon content in the crude oil contaminated soil was enhanced by activity of indigenous microbes and various biostimulants. Pumpkin leave recorded the highest value of $91.08 \%$ degradation level, followed by wood ash $(88.62 \%)$, 
sawdust (62.61\%), without supplement (69.49\%) and control experiment $(3.42 \%)$. This signifies that there was an improvement in the efficiency or degree of remediation offered by the various biostimulants and indigenous microorganisms.

Also it was observed that pumpkin leave and wood ash were more effective in degrading crude oil contaminated soil but sawdust appeared to have inhibited the activities of the microbes as this gave a lower efficiency compared to without supplement.

\section{REFERENCE}

[1] Yuniati, M.D. (2018). Bioremediation of PetroleumContaminated Soil, Review. IOP conference series: Earth and Environmental Science 118: 1315 - 1755.

[2] Khali, J., Abdullah.S., Mahmoud, E.and Arshad A.(2017). Income and Price Elasticities of Crude Oil Demand in Pakistan. Global Business Review 18(6): 1-11. Sage publications.

[3] Ofoegbu Rowland U, Momoh O. L. Yusuf and Nwaogazie L. Ify (2015). Bioremediation of Crude Oil Contaminated Soil Using Organic and Inorganic Fertilizers. Pet Environ Biotechnol, 6:1

[4] Adams, F.V., Niyomugabo, N. and Sylvester, P.O. (2017). Bioremediation of Crude oil Contaminated Soil using Agricultural wastes. Procedia Manufacturing 7:459 - 464

[5] Onwurah, I.N.E. (2007). Crude oil spills in the environment, effects and some innovative clean up biotechnologies. Int. J. Environ. Res., 1: 307-320.

[6] Wang, X., Zheng, J., Han, Z. and Chen, H. (2019). Bioremediation of crude oil- contaminated soil by hydrocarbondegrading microorganisms immobilized on humic-acid modified biofuel ash. Journal of Chemical Technology and Biotechnology. 94:1904-1912

[7] Modupe, E.O., Moses, E.E., Damilola, E.B. and Joshua, O.O. (2017). In situ Bioremediation of Crude Petroleum Oil polluted Soil Using Mathematical Experimentation. International Journal of Chemical Engineering. 1:1-11.

[8] Das, N. and Chandran P. (2011). Microbial degradation of petroleum hydrocarbon contaminants: an overview: Biotechnology Research International Article ID 941810, 13 pages.

[9] Holliger C., Gaspard S. and Glod G. (1997). Contaminated Environments in the Surface and Bioremediation; Organic Contaminants FEMS Microbiology Reviews, Vol 20; no.3-4, pp 517-523.

[10] Kvenvolden K.A and Cooper C.K.(2003). "Natural Seepage of Crude Oil into the Marine Environment" Geo-Marine Letters Vol 23, no: 3-4, pp140-146.

[11] Borah, D and Yadav, R.N.S.(2016). Bioremediation of petroleum based contaminantswith biosurfactant produced by a newly isolated petroleum oil degrading bacterial strain. Egyptian Journal of Pet. 26: $181-188$.

[12] Nwogu, T.P., Azubuike, C.C. and Ogugbue, C.J. (2015). Enhanced bioremediation of soil artificially contaminated with petroleum hydrocarbon after amendment with capraegagrus hircus (Goat) Manure. Biotechnology Resource International 1: 1-7.

[13] Esmaeli, A.S.T. and Akbar. A.(2015). Occurrence of pseudomonas aeruginosa in Kuwait soil.Chemosphere 120:100107.

[14] Baptista, S.J., Cammarota, M.C., and Freire, D.D.D.C. (2005). Production of $\mathrm{CO}_{2}$ in the bioremediation in Clay soil. Braz. Arch. Biol. Technol. 48:249-255.

[15] Andreolli, M., Lampis, S., Brignoli P. and Vallini, G. (2015). Bioaugmentation and biostimulation as strategies for the bioremediation of a burned Woodland soil contaminated by toxic hydrocarbons: A Comparative Study. Journal of Environmental Management 153: $121-131$.

[16] Vidali, M. (2001). Bioremediation: An Overview. Pure Applied Chemistry 73:1163-304.
[17] Venosa A.D., Lee K., Suidan M.T.,Gaicia-Blanco S. and Cabanli S.(2002).Bioremediation and biorestoration of crude oil contaminated fresh water Wetland on St. Lawrence River.Bioremediation Journal 6:261-281.

[18] Adesodun, J.K., and Mbagwu, J.S.C. (2008). Biodegradation of waste lubricating petroleum oil in a tropical alfisol as mediated by animal droppings. Bioresour. Technol. 99:5659-5665.

[19] Otokunefor, T.V. and Obiukwu, C. (2010). Efficacy of inorganic nutrients in Bioremediation of a Refinery Effluent. Scientia Africana, 9(1): 111-125.

[20] Yi, H. and Crowley, D.E. (2007). Biostimulation of PAH degradation with plants containing high concentrations of Linileic acid. Environmental Science Technology 4: 4382 - 4388.

[21] Rosenberg E., Lagmann, R., Kushmaro A., Tauba R. and Adler R. (1992).Petroleum Bioremediation. A multiphase problem. Bioremediation 3:337-350.

[22] Al- Kindi, S. and Abed, R.M. (2016). Comparing oil degradation efficiency and bacterial communities in contaminated soils subjected to biostimulation using different organic wastes. Water Air Soil Pollution 227: 36 - 47

[23] Marinescu, M., Lacatusu, A., Gament, E., Plopeanu, G., Carabulea, V., and Mihai, M.(2017). A Review of biological methods to remediate crude oil polluted soil. Ann. Univ. CraiovaAgric. Montanol cadastre Ser 46: 335-340

[24] Abioye, P.O., Aziz, A.A and Agamuthu P. (2010). Enhanced biodegradation of used engine oil in soil amended with organic wastes. Water Air Soil Pollution 209: 173 -179. 